\title{
Effect of fermented soybean on growth performance of Nile Tilapia (Oreochromis niloticus)
}

\author{
Noaman, O. $S^{1}$; A. E. Eid ${ }^{2}$; K. A. Elsayed ${ }^{2}$ and B. Abdelfattah ${ }^{2}$ \\ ${ }^{1}$ Engineer for Regional laboratory for food and feed, Agriculture Research Center, Giza, Egypt. \\ ${ }^{2}$ Faculty of Agriculture-Department of Animal Production and Fish Resources- Suez Canal University. Ismailia 41522- Egypt
}

Received: $16 / 7 / 2015$

\begin{abstract}
A feeding trial was conducted to evaluate the effect of replacing diet protein with fermented soybean meal (FSM) on the growth performance, feed utilization, body composition, of Nile tilapia (Oreochromis niloticus) fingerlings . Five isonitrogenic and isocaloric diets were prepared with levels of 0 (control), 25, 50, 75 and $100 \%$ FSM for T1, T2, T3, T4 and T5 respectively. Three hundred Nile tilapia (Oreochromis niloticus) fingerlings with initial weight of $12.78 \pm 0.12 \mathrm{~g}$ were divided into five groups ( 20 fish per tank, Triplicate per treatment). Fingerlings Nile tilapia were hand-fed to visual satiation at two meals per day for 8 weeks (56 days). Fish were fed diets containing different levels of FSM had no significant differences regarding survival. Final and weight gain, SGR, PER and PPV were significantly higher in group of fish on T5 and T4 groups respectively. FCR was the lowest in T5 and T4 compared with the control group. Feed and protein intake was significantly highest in group of fish on T1 and T2 and lowest in T4 and T5. Body protein significantly increased with increasing level of incorporation of fermented soybean meal in the diets. These results indicate that incorporation of fermented soybean meal into fingerlings Nile tilapia diets reduced the price of one $\mathrm{kg}$ diet to $91.17,78.21,74.60$ and $60.25 \%$ for the $\mathrm{T} 2, \mathrm{~T} 3, \mathrm{~T} 4$ and $\mathrm{T} 5$ respectively compared to the control group (100\% of the price).
\end{abstract}

\section{INTRODUCTION}

The Nile tilapia (Oreochromis niloticus) was one of the important fish species cultured in the Egypt. All illustrations from Egyptian tombs, suggest that Nile tilapia were cultured more than 3000 years ago. It is still the most widely cultured fish species in Africa, and it is an important cultured fish group in the world, after carps and salmonids. (FAO, 2009).

Soybean meal (SBM) is commonly used as an effective plant-derived protein in animal feed industry. Fermentation is a process allows microorganisms such as Bacillus subtilis to degrade protein macromolecules to a large extent water-soluble low molecular weight compounds (Kiers et al., 2000). It was found that fermentation of soybean meal induced removal or inactivation of anti-nutritional factors (Reddy and Pierson, 1994; Lim et al., 2010), improvement of the nutritional quality (Canella et al., 1984), improvement of digestibility (Kiers et al., 2000) and shelf life of the processed food (Skrede and Nes, 1988). Fermented fish silage and fermented soybean meal (FSM) were reported as suitable protein sources in the diets of catfish, Claris gariepinus (Burchell) and Nile tilapia Oreochromis niloticus L. (Fagbenro et al., 1994). It was shown that FSM induced higher growth and feed efficiency compared to non-fermented soybean meal in diets of yellowtail Seriola quinqueradiata (Shimeno et al., 1993a and Shiu et al., 2015).

Fermented soybean meal (FSBM) is a microbial treated form of SBM, and is rich in protein $(56 \%)$ and low in ANFs. Antinutritional levels in the FSBM are reducing during the enzymatic degradation and fungal fermentation, and provide many benefits against digestion issues (Kim et al., 1999; Hong et al., 2004). Moreover, the protein quality can be significantly higher than that of SPC due to the low processing temperatures during the microbial process. Over the past decade, there has been a growing interest in evaluating the effects of FSBM inclusion on animal diets, but very little published information addresses the use of FSBM in fish diets (Shimeno et al., 1994; Refstie et al., 2005; Zhou et al., 2011; Yuan et al., 2012).

The aim of the present study is to investigate the effect of replacing protein of diets with fermented soybean meal at levels $25,50,75$ and $100 \%$ on growth performance, feed utilization, body composition and economic efficiency.

\section{MATERIALS AND METHODS}

The experiments were conducted at fish Research center in Suez Canal University Ismailia- Egypt to study the effect of replacing different levels of protein with fermented soybean meal on growth performance of Nile tilapia fingerlings. The experiments were carried out through (5th October-3rd December 2014) 56 days.

The Experiment

Fermentation of soybean meal

Fermentation of soybean meal was applied as the preparation process of the Meju with some modification (Figure 1). Soybean meal was finely ground, soaked with water at a ratio of 1:3 for $40 \mathrm{~min}$ and Cooked for 2 $\mathrm{h}$ at $100^{\circ} \mathrm{C}$.After cooling at $28^{\circ} \mathrm{C}$ and left for air 4 days at $25^{\circ} \mathrm{C}$. The fermented soybean meal (F-SBM) was directly incorporated into the F-SBM diet. The composition of fermented and soybean meal are presented in Table (1).

Table (1): Fermented soybean and soybean meal composition .

\begin{tabular}{lllll}
\hline Ingredient & Crude protein & Crude fat & Crude fiber & Ash \\
\hline Fermented soybean meal & 50 & 0.8 & 9.3 & 6.20 \\
Soybean meal & 44 & 1.1 & 7.3 & 6.3 \\
\hline
\end{tabular}




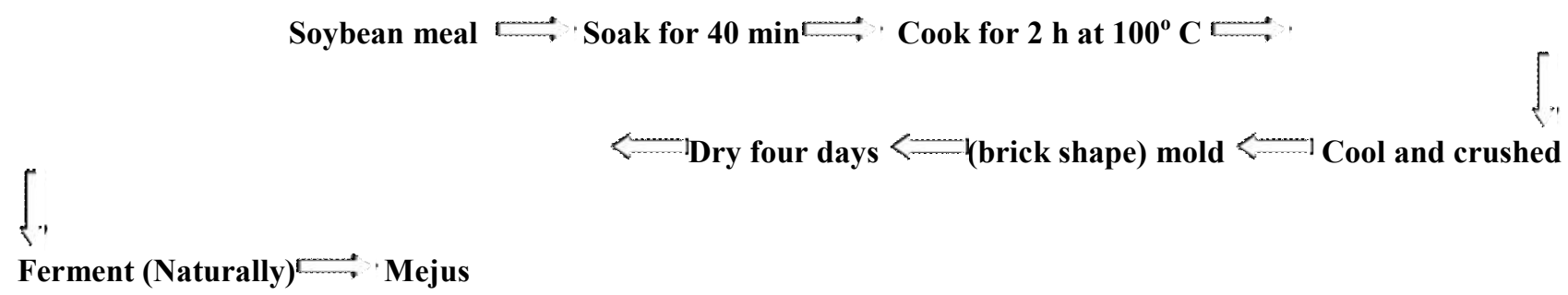

Figure (1). Fermentation processes for Meju and soybean meal (F-SBM).

\section{Experimental diets}

Five isonitrogenous and isocaloric diets were formulated from practical ingredients (Table 2) where the control diet and the other four diets protein content was replaced by $25,50,75$ and $100 \%$ with fermented soybean meal. The composition and proximate analysis of the experimental diets are presented in Table (2). The fish were hand-fed to apparent satiation within half an hour, twice/day (11 am and $3 \mathrm{pm})$ for 56 days. The experimental diets were formulated to contain almost $30 \%$ crude protein. The experimental diets were prepared by individually weighing of each component and by thoroughly mixing the mineral and vitamins with corn. This mixture was added to the components together with oil. Water was added until the mixture became suitable for making granules. The wet mixture was passed through CBM granule machine with $2 \mathrm{~mm}$ diameter. The produced pellets were dried at room temperature and kept frozen until experiment start.

\section{Experimental unit}

Fish were stocked in 15 plastic tank (60 litre) randomly divided into five equal experimental groups (20 fish each treatment, three replicate/treatment) and tanks supported with air blowers. Photoperiod was $12 \mathrm{~h}$ light/ $12 \mathrm{~h}$ dark. Water temperature was maintained at $\left(28 \pm 0.12^{\circ} \mathrm{C}\right)$. The tank water was exchanged with fresh water 2-3 time/week. Tanks were washed and changed with fresh water every 4 weeks.

\section{Experimental fish}

Nile tilapia fingerlings used in this study with average initial weight of $12.78 \pm 0.12 \mathrm{~g}$ were obtained from Fish Research Center, Suez Canal University, Ismailia, Egypt. Fish were homogenous in body weights and apparently healthy, unhealthy fish were removed from tanks, and replace with others healthy. Fish were acclimated to laboratory conditions for 2 weeks before beginning.

Table (2): Experimental diet composition (\%)

\begin{tabular}{lccccc}
\hline Ingredient & $\begin{array}{c}\text { Diet1 } \\
\text { (T1) }\end{array}$ & $\begin{array}{r}\text { Diet2 } \\
\text { (T2) }\end{array}$ & $\begin{array}{r}\text { Diet3 } \\
\text { (T3) }\end{array}$ & $\begin{array}{r}\text { Diet4 } \\
\text { (T4) }\end{array}$ & $\begin{array}{r}\text { Diet5 } \\
\text { (T5) }\end{array}$ \\
\hline Fish meal & 40 & 40 & 40 & 40 & 40 \\
FSBM & - & 127.5 & 255 & 382.5 & 510 \\
SBM & 510 & 382.5 & 255 & 127.5 & - \\
Yellow corn & 30 & 150 & 310 & 330 & 330 \\
Wheat brain & 160 & 100 & 20 & 10 & 10 \\
Rice brain & 160 & 100 & 20 & 10 & 10 \\
Vegetable oil & 60 & 60 & 60 & 60 & 60 \\
Vitamin Mix1 & 10 & 10 & 10 & 10 & 10 \\
Mineral Mix2 & 10 & 10 & 10 & 10 & 10 \\
C.M.C3 & 20 & 20 & 20 & 20 & 20 \\
TOTAL & 1000 & 1000 & 1000 & 1000 & 1000 \\
\hline Chemical Composition (\%) & & & & & \\
\hline Moisture & 7.2 & 7.9 & 8.1 & 8.2 & 7.3 \\
Crude protein & 30.04 & 30.08 & 30.05 & 30.53 & 30.3 \\
Crude fat & 8.94 & 8.92 & 8.66 & 8.68 & 8.64 \\
Crude fiber & 6.46 & 5.62 & 5.42 & 5.49 & 5.75 \\
Ash & 4.24 & 4.42 & 4.32 & 4.18 & 4.21 \\
NFE & 43.12 & 43.06 & 43.45 & 42.92 & 43.80 \\
Growth Energy & 431.43 & 431.22 & 430.19 & 430.92 & 432.86 \\
Kcal/Kg & & & & & \\
P/E & 69.63 & 69.75 & 69.85 & 70.84 & 69.99 \\
\hline
\end{tabular}

1 each $\mathrm{Kg}$ vitamin \& mineral mixture premix contained Vitamin A, 4.8 million IU, D3, 0.8 million IU;

E, 4 g; K, 0.8 g; B1, 0.4 g; Riboflavin, 1.6 g; B6, 0.6 g, B12, 4 mg; Pantothenic acid, 4 g; Nicotinic acid,

$8 \mathrm{~g}$; Folic acid, $0.4 \mathrm{~g}$ Biotin, $20 \mathrm{mg}$,

2. Each Kg minerals Mn, 22 g; Zn, 22 g; Fe, 12 g; Cu, 4 g; I, 0.4 g, Selenium, 0.4 g and Co, 4.8 mg.

3.Carboxyl methyl cellulose

4. Nitrogen Free Extract $=100-(\%$ Protein $+\%$ Fat $+\%$ Fiber $+\%$ Ash $)$.

5.Gross Energy based on protein $(5.65 \mathrm{Kcal} / \mathrm{g})$, fat $(9.45 \mathrm{Kcal} / \mathrm{g})$ and carbohydrate $(4.11 \mathrm{Kcal} / \mathrm{g})$. According to (NRC, 1993).

6.Protein Energy Ratio. ( mg protein / Kcal / GE) 


\section{Experimental Practices \\ Samples of fish}

At the start and the end of the main experimental period (56 day), 5 fish were randomly taken from each experimental group. Fish were analyzed for chemical analysis of the whole body by using standard methods AOAC, 1995.

The tested diets were analyzed for crude protein $(\mathrm{CP} \%)$ ether extract $(\mathrm{EE} \%)$, Crude fiber $(\mathrm{CF} \%)$, ash $(\%)$ and moisture according to the procedures described by standard AOAC methods (1995). The nitrogen freeextract (NFE\%) was calculated by differences.

\section{Acclimation and Weighing Procedure}

Prior to initiation of each experiment, fish underwent a week conditioning, during which they readily adjusted to a commercial diet. At the beginning of the experiment, fish were individually weighed every two weeks. Fish weighed on a UWE MJW-300 balance to the nearest $0.01 \mathrm{~g}$. Fish were weighed individually at the beginning and end of feeding trial, and bulkweighed fortnightly in between.

\section{Fish Feeding}

Fingerlings Nile tilapia was fed to satiation two times daily (10:00 am, 3:00 pm) and body weight were recorded every two weeks. After a stipulated period of feeding (20 to $30 \mathrm{~min}$.), unconsumed feed, if any was collected on a fine mesh sieve, dried weighed and subtracted from food offered. Fish were deprived of food on the day of weighing and tanks were thoroughly scrubbed and rinsed with water. Each treatment had three replicates and was fed according to the experimental protocol.

\section{Growth performance parameters:}

The growth performance parameters are calculated according to the following equations:

Average Weight Gain (AWG):-

$(\mathrm{AWG})=$ Average final weight $(\mathrm{g})-$ Average initial weight $(\mathrm{g})$

\section{Average Daily Gain (ADG):-}

$(\mathrm{ADG})=[$ Average final weight $(\mathrm{g})-$ Average initial weight (g)] / time (days)

Specific Growth Rate (SGR \%/day):-

$(\mathrm{SGR} \% /$ day $)=100[\mathrm{Ln} \mathrm{Wt1}-\mathrm{Ln} \mathrm{Wt} 0 / \mathrm{t}]$

Where: - Ln: normal log Wt 0: initial weight (g).

Wt 1: final weight $(\mathrm{g}) \quad \mathrm{T}$ : time of days.

Feed and protein utilization parameters:

Feed and protein utilization parameters are calculated according to the following equations:-

\section{Feed Conversion Ratio (FCR):-}

$\mathrm{FCR}=$ Total feed consumption/ weight gain.

Feed efficiency (FE):-

$\mathrm{FE}=$ weight gain/ Total feed consumption

Protein efficiency ratio (PER):-

PER = body weight gain $(\mathrm{g}) /$ protein intake $(\mathrm{g})$.

Protein production value (PPV, \%):-

PPV $(\%)=100$ [Retained protein $(\mathrm{g}) /$ protein intake].

Survival rate (SR, \%):

$\mathrm{SR}=\mathrm{Ni} \times 100 / \mathrm{N} 0$

\section{Water quality parameters:}

Water temperature were recorded daily by Mercury thermometer where the average range of temperature $28 \pm$ $0.12^{\circ} \mathrm{C}$, and dissolved oxygen by metteler Toledo, model 128.s/No1242 where the average range of dissolved oxygen was above $7 \pm 0.0 .64 \mathrm{mg} / \mathrm{l}$, ammonia measured every two days by Hanna instruments where the average range of total ammonia was $0.009-0.012 \mathrm{mg} / \mathrm{l}$. Other water quality parameters including $\mathrm{pH}$ was measured every two days by $\mathrm{pH}$ meter (Extech $\mathrm{pH} /$ temp pen model $\mathrm{pH}$ 60) where the average range of $\mathrm{pH}$ was in $7.5 \pm 0.7$ during the experiment.

\section{Statistical analysis}

The data obtained in this study were analyzed by one-way ANOVA procedure of Statistical Analysis System (SAS, 1998). Means were compared by Duncan's new multiple range test Duncan (1955).

\section{Economical Evaluation:}

The cost of feed to raise unit biomass of fish was estimated by a simple economic analysis. The estimation was based on local retail sale market price of all the dietary ingredients at the time of the study (Eid and Mohamed, 2008).

Cost $/ \mathbf{k g} \operatorname{diet}(\mathbf{L E})=$ Cost per Kg diet L.E.

Consumed feed to produce $1 \mathrm{~kg}$ fish $(\mathrm{kg})=$

Feed intake per fish per period/ final weight per fish $\mathrm{Kg} / \mathrm{Kg}$

Feed cost per $\mathbf{k g}$ fresh fish $(\mathbf{L E})=$ Step $1 \mathrm{X}$ step 2

Relative \% of feed cost $/ \mathbf{k g}$ fish $=$ Respective figures for step 3/ highest figure in this step

Feed cost $/ \mathbf{1 K g}$ gain $(\mathbf{L E})=$ Feed intake per $\mathrm{Kg}$ gain $\mathrm{X}$ step 1

Relative \% of feed cost of Kg gain =

Respective figures for step 5/ highest figure in this step

\section{RESULTS AND DISCUSSION}

\section{Growth performance}

Averages of initial weights, final body weights $(\mathrm{g})$ and the weight gain (g/ fish) are presented in Table 3 . As presented in this table averages of initial weights had ranged between 12.62 to $12.91 \mathrm{~g}$ with insignificant differences $(p>0.05)$ among the experimental groups. The group of fish on $\mathrm{T} 4$ and $\mathrm{T} 5$ had significantly highest $(\mathrm{P}<0.05) \mathrm{FBW}$, weight gain, SGR while the lowest values of FBW were recorded in group of fish in T1. Therefore, several practical ways have been suggested to improve utilization of plant proteins including; blending Jackson et al (1982) and fermentation Kader et al (2012). Day and Gonzalez (2000). So, the improved growth performance of fish is attributed to a number of factors including improved palatability, digestibility and reduced exposure to antinutritional factors. These results are in agreement with Hammed (2012) for fingerlings African catfish, Clarias gariepinus. And, also Khalafalla (2013) when was used Digeston-1 (fermented soybean meal) for Nile tilapia (Oreochromis niloticus) fingerlings at level $(0.5 \%$ and $0.7 \%$ ). Table (2) showed that treatment applied had no effect on survival rate throughout the experimental period. These results are in agreement with Hammed (2012) found no significant difference $(\mathrm{P}>0.05)$ in mortality for Clarias gariepinus fingerlings. These results indicate that increase the levels of fermented soy bean meal (FSBM) improved growth performance of Nile tilapia fingerlings. This may be improving its 
nutritional quality though its effect on the antinutritional factors present in the soy bean meal. These results may lead us to recommend the replacement of fermented soy bean meal on diets of Nile tilapia fingerlings at $100 \%$ levels.

\section{Effects on feed utilization}

Results of nutrient utilization in terms of feed conversion ratio (FCR): protein

Efficiency ratio (PER) and protein productive value (PPV) are illustrated in Table (3). It was found a significantly $(\mathrm{P}<0.05)$ different among experimental groups. The highest value of feed and protein intake was recorded in group of fish fed diet T1 and T2 followed by $\mathrm{T} 3 \mathrm{~T} 4$ and $\mathrm{T} 5$ respectively. The best value of feed conversion ratio was recorded for T5 (1.34) and T4 (1.43) while the lowest feed conversion ratio value was recorded for T1 (2.12) followed by T2 (1.90) and T3 (1.6) respectively. The same trend was observed in PER T5 (2.48) and T4 (2.32) and PPV were T5 (53.27) and T4 (46.88). Jiao et al. (1992) found that the fermentation leads to bio-modification of the substrate. Modification can also be done by treating the soybean products directly with enzymes. These results are in agreement with the finding of Hammed (2012) for Clarias gariepinus fingerlings. Also, Khalafalla (2013) reported that when used digestion-1 (fermented soybean meal) for Nile tilapia (Oreochromis niloticus) fingerlings at level $(0.5 \%$ and $0.7 \%)$. These results may indicate that fermented soy bean meal could replace up to $100 \%$ by soy bean meal in growing tilapia diets without any adverse effect on feed utilization parameters FCR or PER, As presented in Table (3).

\section{Whole body composition}

Average of whole body chemical compositions including crude protein (CP) ether extracts (EE), ash, nitrogen free extract (NFE) are presented in Table (4). Average of DM contents in tilapia bodies were found to be $(23.83,22.70,22.63,22.40$ and 22.25$)$ for $\mathrm{T} 1, \mathrm{~T} 2$, $\mathrm{T} 3$, T4 and T5 respectively. It was found no significantly $(\mathrm{P}<0.05)$ different among experimental groups. The same trend was observed with ether extracts (EE) and Ash content contents in dry matter of tilapia whole bodies. Hong et al. (2004) showed that after fermentation with Aspergillus oryzae GB-107, the trypsin inhibitor in soy meal was reduced from 2.70 $\mathrm{mg} / \mathrm{g}$ to $0.42 \mathrm{mg} / \mathrm{g}$.. The trypsin inhibitor may be degraded or modified during fermentation and lose its activity binding to trypsin. These results are in agreement with the finding of Khalafalla (2013) who used digestion-1 (fermented soybean meal) for Nile tilapia (Oreochromis niloticus) at level $(0.5 \%$ and $0.7 \%$ ). Liyan Chen (2013) found that dry matter content kept decreasing during fermentation, in parallel with the trend of protein increase. Average of $\mathrm{CP}$ was found to be a significantly $(\mathrm{P}<0.05)$ different among experimental groups .The highest value of crude protein contents was recorded in T5 $(58.40 \%)$ while the lowest value of crude protein contents was recorded in $\mathrm{T} 1$ (56.49. These results in agreement with the finding of Khalafalla (2013) for Nile tilapia (Oreochromis niloticus ).

Table (3): Growth Performance and feed utilization by Nile tilapia fingerlings fed experimental diets.

\begin{tabular}{|c|c|c|c|c|c|}
\hline ITEM & $\begin{array}{l}\text { Diet1 } \\
\text { (T1) }\end{array}$ & $\begin{array}{l}\text { Diet2 } \\
\text { (T2) }\end{array}$ & $\begin{array}{l}\text { Diet3 } \\
\text { (T3) }\end{array}$ & $\begin{array}{l}\text { Diet4 } \\
\text { (T4) }\end{array}$ & $\begin{array}{l}\text { Diet5 } \\
\text { (T5) }\end{array}$ \\
\hline $\begin{array}{l}\text { Average initial body } \\
\text { weight }(I B W) g\end{array}$ & $12.62 \pm 0.10$ & $12.57 \pm 0.12$ & $12.89 \pm 0.13$ & $12.91 \pm 0.15$ & $12.91 \pm 0.14$ \\
\hline $\begin{array}{l}\text { Average final body } \\
\text { weight }(F B W) g\end{array}$ & $30.12^{c} \pm 0.26$ & $31.80^{\mathrm{c}} \pm 0.24$ & $34.31^{\mathrm{b}} \pm 0.23$ & $36.39^{\mathrm{a}} \pm 0.25$ & $37.16^{\mathrm{a}} \pm 0.20$ \\
\hline $\begin{array}{l}\text { Average body } \\
\text { weight gain (g) }\end{array}$ & $17.50^{c} \pm 0.23$ & $19.23^{c} \pm 0.22$ & $21.42^{\mathrm{b}} \pm 0.21$ & $23.48^{\mathrm{a}} \pm 0.24$ & $24.25^{\mathrm{a}} \pm 0.22$ \\
\hline SGR \% day & $1.56^{\mathrm{c}} \pm 0.10$ & $1.65^{\mathrm{c}} \pm 0.01$ & $1.74^{\mathrm{b}} \pm[\backslash 0.02$ & $1.84^{\mathrm{a}} \pm 0.03$ & $1.88^{\mathrm{a}} \pm 0.04$ \\
\hline Survival rate \% & $100 \%$ & $100 \%$ & $100 \%$ & $100 \%$ & $100 \%$ \\
\hline Feed intake(g)/ fish & $37.1^{\mathrm{a}} \pm 0.15$ & $36.53^{\mathrm{a}} \pm .01$ & $34.27^{\mathrm{b}} \pm 0.22$ & $33.72^{c} \pm 0.13$ & $32.55^{\mathrm{c}} \pm 0.02$ \\
\hline CP intake (g)/fish & $11.13^{\mathrm{a}} \pm 0.20$ & $10.95^{\mathrm{a}} \pm 0.15$ & $10.28^{\mathrm{b}} \pm 0.13$ & $10.11^{\mathrm{c}} \pm 0.14$ & $9.76^{c} \pm 0.21$ \\
\hline $\operatorname{FCR}(g / g)$ & $2.12^{\mathrm{a}} \pm 0.01$ & $1.90^{\mathrm{b}} \pm 0.02$ & $1.60^{\mathrm{c}} \pm 0.10$ & $1.43^{\mathrm{d}} \pm 0.22$ & $1.34^{\mathrm{e}} \pm 0.21$ \\
\hline $\operatorname{PER}(g / g)$ & $1.57^{\mathrm{e}} \pm 0.14$ & $1.75^{\mathrm{d}} \pm 0.10$ & $2.08^{\mathrm{c}} \pm 0.12$ & $2.32^{b} \pm 0.13$ & $2.48^{\mathrm{a}} \pm 0.15$ \\
\hline PPV (\%) & $29.55^{\mathrm{e}} \pm 0.12$ & $30.95^{\mathrm{d}} \pm 0.13 \mathrm{c}$ & $44.35^{\mathrm{c}} \pm 0.13 \mathrm{c}$ & $46.88^{\mathrm{b}} \pm 0.10$ & $53.27^{\mathrm{a}} \pm 0.12$ \\
\hline
\end{tabular}


Table (4): Chemical composition of the whole body of Nile tilapia fed experimental diet (\%DM).

\begin{tabular}{lcccccc}
\hline Treatment & Initial & T1 & T2 & T3 & T4 & T5 \\
\hline Dry matter & 25.80 & $23.83 \pm 0.01$ & $22.70 \pm 0.02$ & $22.63 \pm 0.22$ & $22.40 \pm 0.21$ & $22.25 \pm 0.20$ \\
Crude protein & 53.15 & $56.49^{\mathrm{cb}} \pm 0.23$ & $56.50^{\mathrm{cb}} \pm 0.26$ & $57.76^{\mathrm{b}} \pm 0.24$ & $57.94^{\mathrm{b}} \pm 0.20$ & $58.40^{\mathrm{a}} \pm 0.25$ \\
Ether extract & 15.98 & $18.90 \pm 0.10$ & $18.78 \pm 0.12$ & $18.69 \pm 0.13$ & $18.60 \pm 0.15$ & $18.73 \pm 0.14$ \\
Ash & 21.26 & $23.98 \pm 0.10$ & $23.88 \pm 0.01$ & $23.66 \pm 0.02$ & $23 . .59 \pm 0.03$ & $23.55 \pm 0.04$ \\
\hline
\end{tabular}

Means in the same row having different superscript letters are significantly different $(\mathrm{P}<0.05)$.

\section{Economic Evaluation}

Results of Economic Evaluation including feed costs of one $\mathrm{kg}$ gain in weight and its ratio to that of the control group are presented in Table (5). As presented in this Table cost of one $\mathrm{kg}$ of the diet for fermented soy bean meal in T1, T2, T3, T4 and T5 were 4.44, 4.52, 4.60, 4.68 and $4.77 \mathrm{LE}$, respectively. Costs of one $\mathrm{kg}$ gain in weight were 9.41, 8.58, 7.36, 7.02 and 5.67 LE for T1, T2, T3, T4 and T5 respectively. These results indicate that incorporation of fermented soybean meal into tilapia diets reduced the price of one $\mathrm{kg}$ diet to 91.17 , $78.21,74.60$ and $60.25 \%$ for the T2, T3, T4 and T5 respectively compared to the control group $(100 \%$ of the price). These results are in agreement with the finding of Hammed (2012) for Clarias gariepinus fingerlings and also of Khalafalla (2013) who used digestion-1 (fermented soybean meal) for Nile tilapia (Oreochromis niloticus) at level $(0.5 \%$ and $0.7 \%)$.

Table (5): Effect of different dietary fermented soy bean meal levels on the economic efficiency of Nile Tilapia (Oreochromis niloticus).

\begin{tabular}{lcccc}
\hline Treatment & $\begin{array}{c}\text { Feed cost/Kg } \\
\text { diet (LE) }\end{array}$ & $\begin{array}{c}\text { Feed } \\
\text { conversion } \\
\text { ratio }\end{array}$ & $\begin{array}{c}\text { Feed cost/Kg } \\
\text { fresh fish(LE) }\end{array}$ & $\begin{array}{c}\text { Relative feed } \\
\text { cost/Kg fresh } \\
\text { fish (\%) }\end{array}$ \\
\hline T1 & 4.44 & 2.12 & 9.41 & 100.000 \\
T2 & 4.52 & 1.9 & 8.58 & 91.17 \\
T3 & 4.60 & & 7.36 & 78.21 \\
T4 & 4.68 & 1.6 & 7.02 & 74.60 \\
T5 & 4.77 & 1.5 & 5.67 & 60.25 \\
\hline
\end{tabular}

\section{CONCLUSION}

This study indicated that fermented soybean meal can be used to replace up to $100 \%$ of protein for optimum growth Performance, feed utilization and cost efficiency in the diet of fingerlings of Nile Tilapia (Oreochromis niloticus).

\section{REFERENCES}

A. O. A. C. (1995). Association of official analytical chemists, official methods of analysis. $16^{\text {Th }}$ edition, AOAC, Arlington, VA. 1832.

Canella, M., A. Bernardi and D. Marghinott (1984). Improvement of germinated sunflower meal by fermentation. Journal of Food Science and Technology, 17: 314.
Day O. J. and G. H. Plascencia Gonzalez (2000) Soybean protein concentrate as a protein source for turbot (Scophthalmus maximus L). Aquaculture Nutrition, 6: 221-228.

Duncan, D. B. (1955). Multiple range ad multiple Ftest. Biometrics, 11: 1- 42.

Eid A.-H. and K. A. Mohamed (2008). Effect of using probiotic as growth promoters in commercial diets monosex Nile tilapia (Oreochromis niloticus) fingerlings. 8th International symposium on tilapia in aquaculture

Fagbenro, O., K. Juancey and G. Haylor (1994) Nutritive value of diets containing dried loetic acid fermented fish silage and soybean meal for juvenile $O$. niloticus and clarias gariepinus. Aquatic living Resource, 39: 79 - 85, 
FAO, Food and Agriculture Organization of the United Nations. (2009). (2007) FAO yearbook. Fishery and aquaculture statistics. http://www.fao.org/fishery/publications/yearbooks/en

Hammed, L. O. (2012). replacement of commercial soybean meal with fermented soybean meal in the diets of African catfish, clarias gariepinus fingerlings a Dissertation Submitted to the Department of Aquaculture and Fisheries Management, College of Environmental Resources Management, Federal University of Agriculture, Abeokuta in partial fulfillment of the requirements for the degree of Master in Aquaculture and Fisheries Management.

Hong, K. J., C. H. Lee, S. W. Kim (2004). Aspergillus oryzae 3.042GB-107fermentation improves nutritional quality of food soybeans and feed soybean meals. J. Med. Food 7(4): 430-434.

Jackson A. J., B. S. Capper and A. J. Matty (1982). Evaluation of some plant proteins in complete diets for the tilapia (Sarotheroden mossambicus). Aquaculture 27: 97-109

Jiao, J. A., B. C. Yee, K. Kobrehel and B. B. Buchanan (1992). Effect of thioredoxin linked reduction on the activity and stability of the Kunitz and Bowman-Birk trypsin inhibitor proteins. Journal of Agricultural and Food Chemistry 40(12): 23332336.

Kader, M. A., S. Koshio, M. Ishikawa, S. Yokoyama, M. Bulbul, B. T. Nguyen, J. Goa and A. Laining (2012). Can fermented soybean meal and squid byproduct blend be used as fishmeal replacements for Japanese flounder (Paralichthys olivaceus)? Aquaculture Research 43: 1427-1438.

Khalafalla M. M. (2013) Nutritive Value of Diets Containing Digeston-1 as a Feed Additive for Nile Tilapia (Oreochromis niloticus) Fingerlings J Aquac Res Development 4: 192 doi:10.4172/21559546.1000192.

Kiers, J. L., A. E. Van Laeken, F. M. Rombouts and M. J. Nout (2000). In vitro digestibility of bacillus fermented soya bean. International Journal of Food Microbiology 60(2-3): 163-169.

Kim, B. N., J. L. Yang and Y. S. Song (1999). Physiological functions of chongkukjang. Food and Nutrition 4:40-46.

Lim S. J., S. S. Kim, M. A. Pham, J. W. Song, J. H. Cha, J. D. Kim, J. U. Kim and K. J. Lee (2010). Effects of fermented cottonseed and soybean meal with phytase supplementation on gossypol degradation, phosphorus availability, and growth performance of olive flounder (Paralichthys olivaceus). Fisheries and Aquatic Sciences 13: 284-293.
Liyan Chen. (2013) detoxification and nutritional enhancement of soy meal via microbial bioprocessing a Dissertation submitted to Department of Grain Science and Industry College of Agriculture Kansas State University Manhattan, Kansas in partial fulfillment of the requirements for the degree Doctor of philosophy.

NRC (National Research Council). (1993). Nutrient requirements of fish. Committee on Animal Nutrition. Board on Agriculture. National Research Council. National Academy Press. Washington DC, USA.

Reddy N. R. and M. D. Pierson (1994). Reduction in anti-nutritional and toxic components in plant foods by fermentation. Food Research International, 27: 281-290.

Refstie S., S. Sahlstrfm, E. Brathen, G. Baeverfjord and P. Krogedal (2005). Lactic acid fermentation eliminates indigestible carbohydrates and antinutritional factors in soybean meal for Atlantic salmon (Salmo salar). Aquaculture, 246: 331-345.

SAS Institute (1998). SAS statistical guide for personal computer, SAS Institute Inc. Cary, NC.

Shimeno S., T. Mima, O. Yamamoto and Y. Ando (1993a). Effects of fermented defatted soybean meal in diet on growth feed conversion and body composition of juvenile yellowtail. Nippon Suisan Gakkaishi, 59: 1883-1888.

Shimeno, S., A. Hashimoto, Y. Ando and K. Hayakawa (1994). Improving the nutritive value of defatted soybean meal through purification and fermentation for fingerling yellowtail. Suisanzoshoku, 42: 247-252.

Shiu Y. L., W. C. Guei, Y. C. Shin and C. H. Liu (2015). Increase in the plant protein ratio in the diet of white shrimp, Litopenaeus vannamei (Boone), using Bacillus subtilis E20-fermented soybean meal as a replacement. Aquaculture Research, 46: 382-394.

Skrede A. and I. F. Nes (1988). Slaughterhouse byproducts preserved by (Lactobacillus plantarum) fermentation as feed for mink and foxes. Animal Feed Science and Technology, 20: 287-298.

Yuan, Y. C., Y. C. Lin, H. J. Yang, Y. Gong, S. Y. Gong and D. H. Yu (2012). Evaluation of fermented soybean meal in the practical diets for juvenile Chinese sucker, Myxocyprinus asiaticus. Aquaculture Nutrition. http://dx.doi.org/10.1111/j.1365-2095.2012.00939.x.

Zhou, F., W. Song, Q. Shao, X. Peng, J. Xiao, Y. Hua, B. N. Owari, T. Zhang and W. K. Ng (2011). Partial Replacement of Fish Meal by Fermented Soybean Meal in Diets for Black Sea Bream, Acanthopagrus schlegelii, Juveniles. Journal of the World Aquaculture Society, 42: 184-197. 


\section{تأثير مسحوق الصويا المخمر على أداء النمو لسمك البلطي النيلى

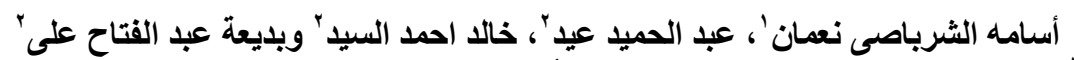

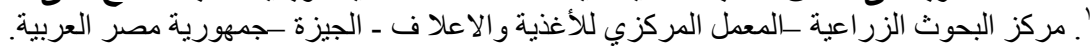

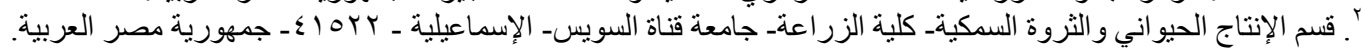

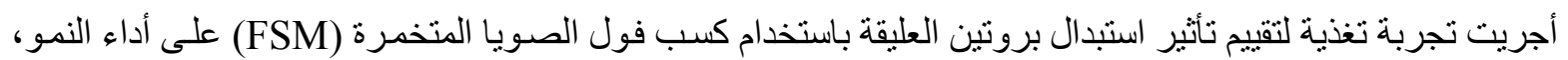

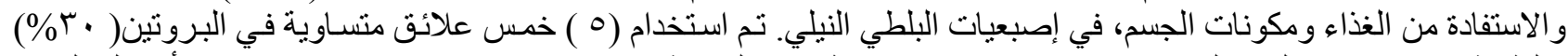

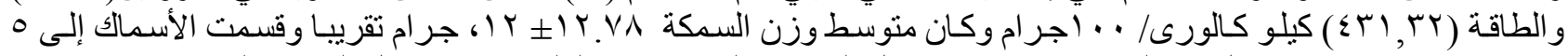

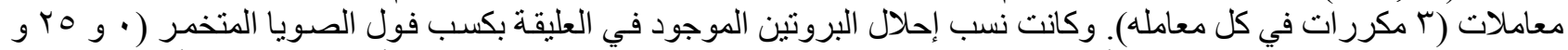

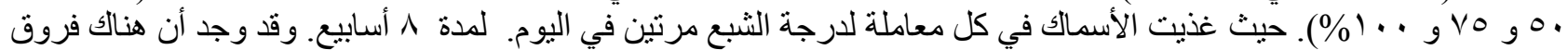

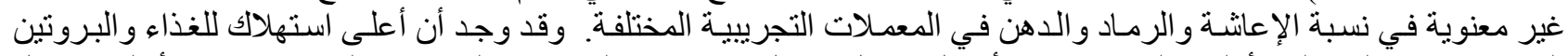

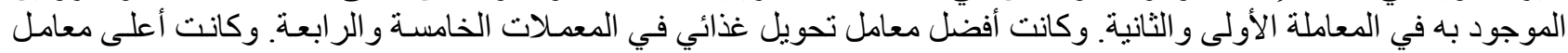

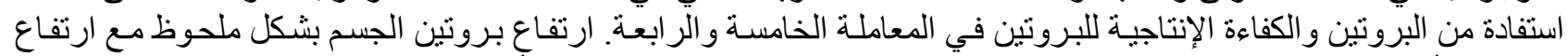

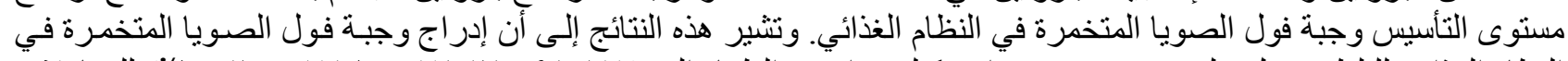

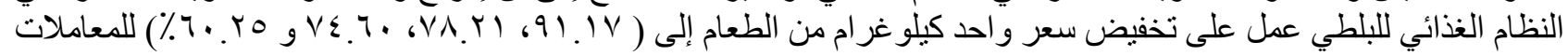

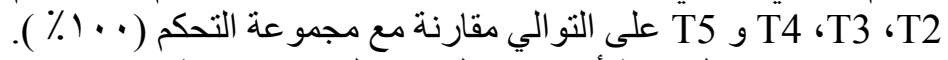

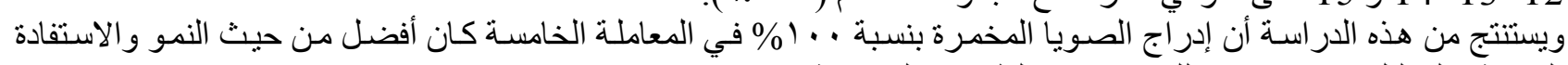
الغذائية و التحليل الاقتصادي وذنة اللك تحت هذه الظروف الفر التجريبية. 